Araştırma Makalesi

\title{
Çocuklara Yönelik Televizyon Reklamcılığında Ebeveyn Algılarının Tutum ve Arabuluculukları Üzerine Etkisi: Kocaeli (Gölcük)'de Bir Araştırma
}

\author{
Duygu Talih Akkaya (Dr. Öğr. Üyesi) \\ Yalova Üniversitesi Yalova Meslek Yüksekokulu \\ duygutalih@gmail.com \\ Şeniz Özhan (Dr. Öğr. Üyesi) \\ Tekirdağ Namık Kemal Üniversitesi Çorlu Meslek Yüksekokulu \\ serdem@nku.edu.tr
}

Başvuru Tarihi: 04.03.2021

Yayına Kabul Tarihi: 24.06.2021

Yayınlanma Tarihi: 30.07.2021

https://doi.org/10.17680/erciyesiletisim.890969

\section{Öz}

Özellikle tüketim toplumlarında kilit bir role sahip olan çocuklar için televizyon, hızla gelişen iletişim teknolojilerine rağmen vazgeçilmez bir kitle iletişim aracı olmaya devam etmektedir. Çocuklar televizyon içeriklerinin önemli bir kısmını oluşturan reklamlara çok fazla maruz kalmakta ve özellikle kendilerine yönelik reklamlardan etkilenmektedirler. Ebeveynlerin bu etkilere ilişkin algıları ise, çocuklara yönelik televizyon reklamları ile ilgili tutum ve davranışları üzerinde belirleyici olmaktadır. Bu araştırmanın amacı, ebeveynlerin çocuklara yönelik televizyon reklamlarına ilişkin algılarının tutumları ve arabuluculukları üzerindeki etkilerinin incelenmesidir. Bu amaç doğrultusunda öncelikle çocuklara yönelik televizyon reklamlarının onlar üzerindeki etkileri, ebeveynlerin söz konusu reklamlara yönelik algıları, tutumları ve ebeveyn arabuluculuğu ile ilgili literatür taraması yapılmıştır. Uygulama bölümünde ise ebeveynlerin çocuklara yönelik televizyon reklamlarına ilişkin algılarının tutumları ve arabuluculuklarına etkisinin incelenmesi amacıyla hazırlanan anket ebeveynler tarafından cevaplandırılmış, 247 ebeveynin cevapları sonucunda elde edilen veriler yapısal eşitlik modeli ile analiz edilmiş ve yorumlanmıştır. Elde edilen sonuçlara göre çocuklara yönelik televizyon reklamlarının etkilerine yönelik olumsuz algıya sahip olan ebeveynlerin söz konusu reklamlara ilişkin olumsuz tutumları olduğu ve çocuklarının televizyon izleme içeriği ve süresi üzerinde kontrol uyguladığı, reklamların bilgi verici olduğuna dair algıların ise ebeveynlerin çocuklarıyla reklam içeriği hakkında konuşmaları üzerinde olumlu yönde etkisi olduğu bulunmuştur. Ayrıca ebeveynlerin çocuklara yönelik televizyon reklamlarına ilişkin tutumlarının çocuklarıyla reklam içeriği hakkında konuşmaları üzerinde olumsuz yönde etkisi olduğu sonucuna varılmıştır.

Anahtar Kelimeler: Reklamcılık, Çocuklara Yönelik Televizyon Reklamları, Ebeveyn Algıları, Ebeveyn Tutumu, Ebeveyn Arabuluculuğu. 


\title{
The Effect of Parents' Perceptions on Their Attitude and Mediation in Television Advertising Toward Children: A Research in Kocaeli (Golcuk)
}

\author{
Duygu Talih Akkaya (Asst. Prof. Dr.) \\ Yalova University Yalova Vocational School \\ duygutalih@gmail.com \\ Şeniz Özhan (Asst. Prof. Dr.) \\ iD Tekirdağ Namık Kemal University Çorlu Vocational School \\ serdem@nku.edu.tr
}

Date Received: 04.03.2021

Date Accepted: 24.06.2021

Date Published: 30.07.2021

https://doi.org/10.17680/erciyesiletisim.890969

\begin{abstract}
Television continues to be an indispensable mass communication tool for children, who have a key role in consumer societies, despite rapidly developing communication technologies. Children are exposed to advertisements, which constitute a significant part of television content, and are particularly affected by advertisements directed to them. Parents' perceptions of these effects are determinative on their attitudes and behaviors about television commercials for children. The aim of this study is to examine the effects of parents' perceptions of television commercials towards children on their attitudes and mediation. For this purpose, a literature review was conducted on the effects of television advertisements for children, parents' perceptions and attitudes towards these advertisements and parental mediation. In the application part, the questionnaire prepared to examine the effect of parents' perceptions of television advertisements towards children on their attitudes and mediation was answered by the parents, and the data obtained as a result of the answers of 247 parents were analyzed with the structural equation model and interpreted. According to the results, parents who have a negative perception of the effects of television advertisements for children have negative attitudes towards these advertisements and exercise control over the content and duration of their children watching television, and perceptions that the advertisements are informative have a positive effect on parents' conversations with their children about the ad content. was found to be. In addition, it was concluded that the attitudes of the parents towards television commercials towards children had a negative effect on their conversations with their children about the advertisement content.
\end{abstract}

Keywords: Advertising, Television Advertising Toward Children, Parental Perceptions, Parental Attitude, Parental Mediation. 


\section{Giriş}

İnternet ve sosyal medyanın büyük bir hızla televizyona rakip olduğu gerçeğine rağmen televizyon, birçok aile için halen sosyalleşmenin ve haber almanın önemli araçlarından biri olarak yerini korumaktadır. Bu durum, ailelerin boş vakit değerlendirme aracı olarak televizyonu görmelerine ve böylelikle çocukların da televizyonla erken yaşta tanışmalarına sebep olmaktadır. Günümüzde eleștirel çalıșmaların merkezinde yer alan televizyon, tüm eleştirilere rağmen halen milyonlarca kişi tarafından vazgeçilmez bir iletişim aracı olarak varlığını sürdürmektedir (Dağlı \& Hacıbektaşoğlu, 2015). Toplumun en küçük bireyleri olan çocuklar ise günümüzde halen en yaygın ve etkili kitle iletişim aracı olan televizyondan etkilenmektedir (Büyükbaykal, 2007). Çocukların ilgisi ve alışkanlıklarının şekillenmesinde oldukça aktif rol oynayan televizyonun onların toplumsallaşması, bilişsel, sosyal ve duygusal gelişimleri üzerinde de muazzam bir etkisi olduğu inkar edilemez bir gerçektir (Karaboğa, 2020) .

TÜİK verilerine göre 2019 yll sonu itibari ile Türkiye nüfusu 83 milyon 154 bin 997 kişi iken bunun 22 milyon 876 bin 798'ini çocuklar oluşturmaktadır (TÜİ, 2020). Yani genel nüfus içerisindeki çocuk oranı \%27.5'tir. Diğer yandan T.C. Radyo ve Televizyon Üst Kurulu Kamuoyu, Yayın Araştırmaları ve Ölçme Dairesi Başkanlığı tarafından 2017-2018 Eğitim Öğretim yılı içerisinde 3029 öğrenci üzerinde yapılan "Çocukların Yeni Medya Kullanım Alışkanlıkları ve Siber Zorbalık 2018 Araştırması" sonuçlarına göre araştırmaya katılan öğrencilerin \%31,3'ünün her gün, \%21,4'ünün hemen hemen haftanın her günü, \%36,9'unun da haftada birkaç gün televizyon izlediği tespit edilmiştir. Aynı araştırmaya göre öğrencilerin günlük ortalama televizyon izleme süreleri ise 1 saat 29 dakikadır (RTÜK, 2018). Çocukların genel nüfus içerisindeki oranının ve televizyon izleme sıklığı ve sürelerinin yüksek olması, pazarlamacıların çocukları doğrudan tüketici olarak hedeflemelerine zemin hazırlamış, markaları, çocukları sosyalleşme süreçlerinde yakalamaya ve onları tüketime yönlendirmeye sürüklemiştir (Bal \& Onay, 2020).

Televizyon akışı içerisinde belki de en filtresizce ve devamlı bir tekrar dahilinde çocukların algı eşiklerinden akıp giden içerikler ise reklamlardır (Engin, 2013). İnternetin ve sosyal medyanın artan varlığına rağmen, televizyon her yaştan çocuğa farklı içeriklerle kolayca ulaşan ana reklam medyası olmaya devam etmektedir (Nefat \& Dujmović, 2012). İçinde barındırdığı kurgu, renkler, müzik, oyuncular, zaman ve mekan gibi estetik unsurlar ile reklamlar çocukların dikkatini çekmekte, tüketim kültürü ve ritüellerinin başlıca katalizörü olarak işlev görmeye devam etmektedir (Engin, 2013).

Televizyon reklamlarının çocuklar üzerindeki etkisini tek bir faktör üzerinden değerlendirmek elbette olanaksızdır. Söz konusu etkiler, çocukların içinde yaşadıkları toplumun, kitle iletişim araçlarının, ebeveynlerinin sahip olduğu sosyal, ekonomik ve kültürel özellikleri ve reklama yönelik algıları ile birlikte şekillenmektedir (Engin, 2013). Birçok araştırma, çocukların birer tüketici olarak görülmelerinin doğru olmadığını, televizyonda yer alan reklamların, söz konusu reklamlara sürekli maruz kalan çocuğun fiziksel ve psikolojik gelişimini olumsuz yönde etkilediğini göstermektedir. Bu araștırma sonuçları ve bilimsel bulgulara karşın, televizyon reklamlarının sıklıkla hedef aldıkları tüketiciler, maalesef ki çocuklardır (Dağlı \& Hacıbektaşoğlu, 2015). Günümüz çocuklarının erken yaşta tanıştıkları markalara bağımlılıkları, alışveriş yapma özgürlüklerinin artması, ebeveynlerinin satın alma kararları üzerinde etkili olmaları çocuklara yönelik ürün pazarının giderek büyümesine ve reklamcıların bu tüketici grubuna gün geçtikçe daha fazla ilgi göstermesine neden olmuştur (İkinci, 2011). Reklamcılar Derneği önderliğinde hazırlanan ve Deloitte tarafından yayınlanan, 2019 Türkiye Medya ve Reklam Yatırımları 
İstatistikleri Raporu incelendiğinde 2019 yılının ilk 6 ayında gerçekleştirilen medya ve reklam harcamaları içerisinde en yüksek yatırımın \% 48.2 ile televizyon reklamlarına yapıldığı görülmektedir (Deloitte, 2019).

Çalışmanın temel amacı, ebeveynlerin çocuklara yönelik televizyon reklamlarına ilişkin algılarının tutumları ve arabuluculukları üzerindeki etkilerinin incelenmesidir. Veriler 247 ebeveynden toplanmış ve analizinde yapısal eşitlik modellemesi (YEM) kullanılmıştır. Çalışmada öncelikle ilgili literatür incelenmiş ve edinilen bilgiler ışığında hipotezler oluşturulmuş, ardından araştırma modelini test etmek üzere gerekli analizlere, bulgulara ve bulgulara ilişkin sonuç ve önerilere yer verilmiştir.

\section{1. Çocuklara Yönelik Televizyon Reklamlarının Çocuklar Üzerindeki Etkileri}

Televizyon reklamları, farklı yaş gruplarındaki bireyleri hedef almakla birlikte en önemli izleyicileri ve tüketicileri arasında çocuklar bulunmaktadır (Karaboğa, 2020). Modern paradigmanın minyatür yetişkini, günümüz post modern toplumun tüketen ve tüketilen nesnesi olarak konumlandırılan çocuk, içinde yaşadığı topluma ve zamana uyumlu olarak çeşitli anlamlar kazanmış bir kavramdır. Önceleri en fazla yedi yașına kadar sürdügü varsayılan çocukluk dönemi, zamanla çeşitli teknolojik gelişmeler ve bunların sosyolojik etkileri ile farklı bir anlam kazanmaya başlamıştır (Vodinalı, 2016).

Çocuklar tüketici olarak sosyalleşirken belli aşamalardan geçmekte ve bu aşamalar reklamcılar ve pazarlamacılar tarafından strateji oluşturulurken dikkate alınmaktadır. Örneğin 3-7 yaş arasındaki algısal dönemde, çocuklar nesneleri tek boyutlu algılamaktadır. Okumayı bilmiyor olmalarına karşın bazı markaları veya reklamlarda yer alan çizgi film karakterlerini tanıyabilmekte ve dikkatlerini çeken bir ürün için talepte bulunabilmektedirler. 7-11 yaş aralığındaki analitik dönemde ise çocuklarda bilişsel ve sosyal yönden büyük gelişmeler yaşanmaktadır. Çocuklar sahip olmak istediği ürünlerin tüm özelliklerini incelemeye başlamakta ve reklamlar ve markalar hakkında daha ayrıntılı bilgiye sahip olabilmektedir. Bir sonraki aşama ise 11-16 yaş aralığını içine alan yansıtıcı dönemdir. Yetişkinliğe geçiş olarak da adlandırılan bu periyotta çocuklar artık marka tercihlerinde bulunurken sosyal çevresinin fikirlerini önemsemekte, tercihlerinde kendi başına kararlar alabilmekte ve bilişsel ve sosyal gelişimlerinde farklı boyuta geçmektedirler (İkinci, 2011).

Çocuklara yönelik televizyon reklamları, çocukların ilgisini çekmek ve bu ilgiyi satın alma davranışına dönüştürmenin yanında, sunduğu tüketici yaşam tarzı ile de onların sosyalleşmeleri üzerinde etkili olabilmektedir. $\mathrm{Bu}$ tür reklamlar, çocukları küçük yaşlardan itibaren tüketim toplumu bireyleri haline getirmeyi hedeflemekte ve bu hedef çerçevesinde reklamcılar, çocukları etkilemek için birtakım ikna yöntemlerine başvurabilmektedir. Reklamların akla ve mantığa değil, duygulara hitap edecek biçimde tasarlanması, reklamlarda ünlü kullanılması, uzmanlara yer verilmesi, mizahın kullanımı, reklamda çocukların oynatılması, müziğin kullanımı başvurulan ikna teknikleri arasındadır (Karaboğa, 2020).

Çocuklar, ilgilerini çeken reklamlardan yetişkinlere göre daha farklı yönde etkilenmektedir. Çünkü yaşam deneyimi az olan, eleştirme yetisi kazanmamış, yalan ile gerçeği ayırt edemeyen çocuklar, yetişkinlere göre çok savunmasız durumdadır (Doğan, 2003). Televizyon reklamlarının çocuklar tarafından tüketilmesi kişisel ve davranışsal gelişimleri açısından birtakım problemler yaratırken, hayal güçlerini ve zihinsel potansiyellerini kullanma, muhakeme yapma ve etkili iletişim kurma gibi becerilerinin gelişimi üzerinde 
olumsuz yansımaları olabilmektedir (Karaboğa, 2020).Reklamlarda kullanılan renkler, hızla değişen görüntüler, abartılı anlatımlar, televizyonda gördükleri her şeyi gerçek sanabilme potansiyeline sahip çocukları psikolojik açıdan olumsuz etkilemektedir (Doğan, 2003). 10 aylık bir bebeğin dahi reklamlardan etkileniyor olmasının ispatı, geleceğin tüketicileri olan çocukların tüketim tercihleri, satın alma modelleri veya marka bağımlılığı gibi kavramların şekillenmesinde televizyon reklamlarının öneminin bir kez daha altını çizmektedir (Elden \& Ulukök, 2006).

Reklamlar, bazı ürünlerin yararlarını abartılı şekilde sunabilmekte, bu da çocukların ilgili ürünlerle ilgili beklentilerini artırabilmektedir. Örneğin, reklamı yapılan ürünün olduğu kazana düşünce hızla büyüyen bir çocuğun yer aldığı bir reklamı izleyen çocuk söz konusu ürünü yiyince hemen büyüyeceği mesajını almaktayken, ürünü yedikten sonra reklamdaki gibi büyümeyince hayal kırıklığı yaşayabilmektedir. Oyuncak reklamlarında fantastik görüntülerin kullanılması da çocukları yanıltabilmekte ve mutsuzluğa itebilmektedir (Karaca, Pekyaman, \& Güney, 2007). Yine sevmediği bir gida ürününün reklamlarından etkilenip ürünü yemeye başlayabilmektedir. Şeker açısından zengin, protein açısından fakir gıdaların televizyondaki reklamları çocukları satın almaya yönlendirebilmektedir (Büyükbaykal, 2007). Bunun yanında televizyon reklamları dilde de bozulmalara neden olabilmektedir. Örneğin, portıkal, çilak kelimeleri, "yiyin gari" gibi sloganları çocuklar çok hızlı ezberlemekte ve devamlı kullanabilmektedir. Ayrıca reklamlarda çocukların kullanımı da yanlış algılamalara yol açabilmektedir. Örneğin, sürekli buzdolabı kapağını açıp kapatan, bulaşık makinesinin kapağında zıplayan, annesine yardım etmesi istendiğinde "yapamam, ellerim yok ki" diyerek asi davranan çocukların ve okulda öğretmenine karşı çıkan öğrencilere yer verilen reklamlar çocukları yanlış yönlendirmektedir (Karaca ve diğerleri, 2007).

Televizyon reklamlarının çocuklar üzerindeki bir başka etkisi ise ebeveyn ve çocukları arasındaki iletişim ve güvene zarar vermesidir. Çocuğun reklamlarda gördügü ürünleri satın aldırmak için diretmesi ve anne-babanın almaması durumunda aralarında çatışma yaşanabilmekte, çocuğa reklamda gördügü ve istediği ürünlerin alınması durumunda ise çocuk ileride doyumsuz bir kişiliğe sahip olabilmektedir (Karaboğa, 2020).

Reklamlar çocukların hayal dünyalarını kısırlaştırmaktadır. Aynı görüntülerle sayısız kez karşılaşan çocuklar düşünmez, sadece izlerler. Çünkü onların düşünmesine gerek kalmadan görüntüler hızla karşılarına gelmektedir. Bu monotonluk çocukların düşünme yeteneklerini köreltmekte, reklamların sık sık tekrarlanması ise çocukların entelektüel mesajları kavrama yeteneklerini azaltmaktadır (Doğan, 2003).

Bazı uzmanlar tarafından reklamların, çocukların beğeni ve tercihlerinin şekillenmesi üzerinde ciddi bir olumsuz etki yarattığına inanılırken bazıları tarafından da çocukların muhakeme yönünü geliştirdiği ve eleştirel bakış açısı kazanmalarında katkıda bulunduğu savunulmaktadır (İkinci, 2011). Masallar gibi çocukları eğlendiren ve rahatlatan bir etkiye sahip olan reklamlar yapısal açıdan da, genellikle dramatik programlara göre, güzelliklere yer veren bölümler olarak görünmektedir (Asena, 2009). Bununla birlikte reklamlar, çocukların seçme özgürlügünü kazanmalarına yardımcı olurken, artan rekabet çocuklar için daha kaliteli ürünler üretilmesini sağlamaktadır. Ayrıca reklamlar, çocuklara çevrelerindeki dünya hakkında çok geniş bir bilgi olanağı sağlayarak onlara bu sayede var olan seçenekler arasında değerlendirme yapabilme yetisini kazandırmaktadır (Pelenk, 2003). 
Bugünün çocukları olan bireyler yarının tüketicileri olacaklardır. Ve küçük yaşlardan itibaren öğrendikleri davranışları ileriki hayatlarında yaşama geçireceklerdir. Bir tüketici olarak neler yapacakları küçükken şekillenirken etkileri ise zamanla ortaya çıkacaktır. Bu yüzden reklamlar çoğunlukla olumsuz düşüncelere sebep olmaktadır (Doğan, 2003).

\section{Ebeveyn Algıları}

Reklâmlar yalnızca yetişkinleri değil, toplumun önemli bir kesimini oluşturan çocukları da hedef alarak, çocukları ve yetişkinleri gereksiz tüketime kanalize etmektedir (Quadır \& Akaroğlu, 2009). Bu durum da ebeveynleri zor durumda bırakmaktadır. Çocuklar tarafından reklamlar eğlenceli bir iletişim unsuru olarak nitelendirilmesine rağmen ebeveynlerin çoğu böyle düşünmemektedir (Dağlı \& Hacıbektaşoğlu, 2015). Tutumlar, ebeveynlerin farklı kültürlerine ve iletişim şekillerine göre değişebilir (Nefat \& Dujmović, 2012). Fakat genellikle ebeveynler için reklam ve televizyon, çocukların fiziksel ve psikolojik açıdan gelişimini sekteye uğratan, en önemlisi de okuma alışkanlığı kazanmasını ve sosyalleşmesini negatif yönde etkileyen unsurlardandır. Ailelerin tüm bu kaygılarına karşın, çocukların boş vakitlerini değerlendirme aracı olarak televizyon ve reklamı tercih etmelerini önlemek mümkün olamamaktadır (Dağlı \& Hacıbektaşoğlu, 2015).

Karaca ve diğerleri (2007) tarafından yapılan bir araştırmada ebeveynlerin büyük çoğunluğu çocuklarının reklamları sevdiğini ancak aynı orantıda reklamları inandırıcı ve etkileyici bulmadıklarını düşündüklerini belirtmişlerdir. Ersoy ve Özbaş'ın (2020) yaptığı araştırmada ise ebeveynlerin çoğunluğu (\%75.90) yayınlanan reklamların çocuklarının hayal gücünü etkilediğini, algı-psikoloji-dil-ahlak-fiziksel gelişim süreçlerinde olumsuz yönlendirme yaptığını düşündüğü ortaya çıkmıștır. Aynı araştırmaya göre ebeveynlerin \%82.1'i, çocuklarının reklamları sevdiğini, bunun reklamdan etkilenmelerini kolaylaştırdığını ve reklamlarda gördüklerine inanma oranını artırdığını, çocuklarının reklamlardaki kişilerin yerinde olmak istediklerini belirten yanıtlar vermiştir. Nefat ve Dujmović (2012) tarafından yapılan araştırmaya göre ise reklam mesajlarının çocuklar üzerindeki etkisine ilişkin olarak genel olarak ebeveynlerin olumlu bir tavrı yoktur. Ebeveynlerin tutumları belirgin şekilde olumsuz olmasa da, reklam mesajlarının çocukların kendilerini çevreleyen dünyayla ilgili bilgilerine katkıda bulunmadığını düşünmektedirler (ortalama değer 2,86).

\subsection{Bilgi Vericilik}

Televizyon reklamlarına sık maruz kalan çocuklar için reklamlar birincil bilgi kaynağıdır (Karaca ve diğerleri, 2007). Televizyon reklamlarının ürün ve hizmetler ile ilgili çocuk tüketicileri bilgilendirdiği ve çocukların gelişim sürecinde etkin ve yararlı bir rolü olduğu yadsınamaz bir gerçektir (Engin, 2013). Çocuklar birtakım reklamlar yoluyla, dişlerini düzenli olarak fırçalaması ve tuvaletten çıkınca ellerini yıkaması gerektiğini, sütün sağlıklı olduğunu bir kez daha hatırlamaktadır (Karaca ve diğerleri, 2007). Ayrıca yine reklamlar aracılığı ile çocuklar bir ürün hakkında her türlü bilgiyi edinmekte ve ürün ve hizmetlerin markaları ve çeşitliliğinden haberdar olmaktadır (Doğan, 2003). Dolayısıyla çocuklar reklamlar yoluyla; ürün ve hizmetleri tanımakta; nereden, nasıl ve hangi fiyatla sağlanıp kullanılacağına (tüketileceğine) yönelik bilgi edinmektedir.

Literatürde yapılan pek çok çalışma ebeveynlerin çocuklara yönelik televizyon reklamlarını bilgi verici bulduğunu göstermektedir. Örneğin, Young, Bruin ve Eagle (2003) tarafından Yeni Zelanda, İngiltere ve İsveç'te yapılan araştırma sonuçlarına göre, Yeni Zelanda'daki ebeveynlerin büyük bir kısmı (ortalama 3,6) ve İngiltere'deki ve 
İsveç’tekilerin ise yarısından fazlası (ortalama 2,68 ve 2,77) çocuklara yönelik televizyon reklamlarının değerli bir bilgi kaynağı olduğunu belirtmişlerdir. Benzer şekilde, Dağlı ve Hacıbektaşoğlu (2015) tarafından yapılan araştırmaya göre ebeveynlerin \%84'ü reklamı yapılan ürünlerin bilgi verici olduğunu düşünmektedir. Yine, Çakır (2019) tarafından yapılan çalışmada da araştırmaya katılan ebeveynlerin çoğu (anne ort. 3,63, baba ort. 3 ,75) reklamların bilgi verici olduğunu belirtmiştir. Bu çalışma bulgularından hareketle, araştırmada ebeveynlerin çocuklara yönelik televizyon reklamlarının bilgi verici olduğuna dair algılarının, tutumları, çocukları ile reklam içerikleri hakkında konuşmaları ve çocuklarına uyguladıkları televizyon izleme kontrolü üzerinde anlamlı bir etkisi olacağı düşünülmüş ve aşağıdaki hipotezler oluşturulmuştur:

H1: Televizyon reklamlarının bilgi verici olduğuna dair ebeveyn algılarının tutumları üzerinde istatistiksel olarak anlamlı bir etkisi vardır.

H2: Televizyon reklamlarının bilgi verici olduğuna dair ebeveyn algılarının çocukları ile reklam içerikleri hakkında konuşmaları üzerinde anlamlı bir etkisi vardır.

H3: Televizyon reklamlarının bilgi verici olduğuna dair ebeveyn algılarının çocuklarına uyguladıkları televizyon izleme kontrolü üzerinde anlamlı bir etkisi vardır.

\subsection{Olumsuz Etki}

Televizyon reklamlarının çocuklar üzerindeki etkileri farklıdır. Ebeveynleri ile ilişkilerine veya eğitim düzeyine göre bu etki daha az ya da daha fazla olabilmekte ve bu etki, çocuğun ulaştığı reklam bilincine göre de değişebilmektedir (Engin, 2013). Çocuklara yönelik televizyon reklamları ile ilgili eleştirilerden bazıları, reklamın yanlış ve yanıltıcı iddialarda bulunması, materyalizm dahil istenmeyen değerleri teşvik etmesi ve savunmasız ve dezavantajlı grupları istismar ettiği yönündedir (Rose, Bush, \& Kahle, 1998).

Çocukların en çok etkilendiği reklamlar, gıda reklamlarıdır. Bu tür reklamların birçoğu çocukları, çikolata, gofret, şeker gibi tatlı yiyeceklere, fast food tarzı beslenmeye yönelterek onların beslenme alışkanlığını olumsuz yönde etkilemektedir. Diğer yandan kültür ve ahlak yönünden de, televizyon reklamlarının olumsuz yönlerinden bahsedilmektedir. Hem henüz ilkokul çağındaki çocukların, birer yetişkin gibi konuşma ve davranmalarına yol açması ve argo kelimelerin kullanılması, hem de reklamlarda bebeklerin ve küçük çocukların yarı çıplak görüntülerine yer verilmesi, yaşanan bu kültürel kirlenmeyi gözler önüne sermektedir. Çocuklara yönelik reklamlar, çocuğun tüketim alışkanlıklarının oluşmasında ve bir tüketici kimliği kazanmasında da önemli bir rol oynamaktadır. Özellikle günümüzde bir birey olarak var olmaya, kendi kişilik ve kararlarını net olarak ortaya koymaya daha erken yaşlarda başlayan çocukların, yoğun iletişim bombardımanının da etkisiyle reklamlara maruz kalma ve onlardan etkilenme oranları daha da yükselmektedir (Asena, 2009).

Literatürde yapılan pek çok çalışma, çocuklara yönelik televizyon reklamlarının çocuklar üzerindeki olumsuz etkilerinden ve ebeveynlerin bu yöndeki algılarından bahsetmektedir. Örneğin, Nefat ve Dujmović (2012) tarafından yapılan araştırmada ebeveynlerin büyük çoğunluğu televizyon reklamlarının, çocuklarının gerçekten ihtiyaç duymadıkları ürünleri istemeye teşvik ettiğini (ortalama değer 4,16), genellikle reklamı yapılan ürünleri talep etmelerine neden olduğunu (ortalama değer 3,97) ve reklamı yapılan ürünleri satın almaları için ebeveynlere baskı yapmalarına yol açtığını belirtmişlerdir (ortalama değer 4,05). Chan ve McNeal (2002) tarafından yapılan çalışmada ise, ebeveynlerin yarısından fazlası (ortalama değer 3,3) çocuklara yönelik televizyon reklamlarının çocuklarına kötü beslenme alışkanlığı kazandırdığını belirtmiştir. Dens, Pelsmacker ve 
Eagle (2007) tarafından yapılan araştırma incelendiğinde pek çok ebeveyn, çocuklara yönelik televizyon reklamlarının çocuklarının yeme alışkanlıklarını etkilediği yönündeki endişelerinden dolayı özellikle gıda reklamlarına karşı olumsuz tavırlar sergilemekte iken diğer araştırmaların aksine ebeveynlerin yalnızca \%20'sinin reklamların çocukları üzerinde etkisi olduğunu düşündüguü ve neredeyse hiçbirinin bunun büyük bir çatışma ve rahatsızlık yarattığına inanmadığı görülmüştür. Yine Young ve diğerleri (2003) tarafından yapılan araştırmaya göre, İngiltere ve İsveç’teki ebeveynlerin birçoğu, çocuklarının reklamlarda gördüğü ve beğendiği ürünleri ailelerine satın aldırmak için baskı yaptıklarını (ortalama 3,57 ve 3,26) ve çocuklarının reklamları ne kadar çok izlerse reklamı yapılan ürünleri o kadar çok talep ettiklerini (ortalama 3,31 ve 3,18) belirtmişlerdir. Doğan'ın (2003) yaptığı çalışmaya göre ebeveynlerin büyük çoğunluğu $(\% 60,2)$ televizyon reklamlarının çocuklarının tüketim alışkanlıklarını değiştirdiğini belirtmişlerdir. Karaca ve diğerleri (2007) ebeveynlerin reklâmlar konusunda en çok şikâyetçi oldukları hususları, ihtiyacın dışında ürün almaya teşvik etmesi, yanlış beslenmeye özendirmesi, tüketim alışkanlıklarını negatif yönde etkilemesi, çocukları savurganlaştırması ve her gördüğünü almaya özendirmesi olarak tespit etmiştir. Dağlı ve Hacıbektaşoğlu (2015) tarafından yapılan araştırmaya göre ebeveynlerin büyük bir kısmı (\%74) çocuklarının reklamlarda söylenen her şeyin doğru olduğuna inandıklarını ve yine büyük çoğunluğunu (\%84) reklamlarda gördükleri ürünlere sahip olmak istediklerini belirtmişlerdir. Ayrıca söz konusu çalışmada ebeveynlerin çocuklarının televizyon seyretmelerine bazen müdahale ettiği, bunun en önemli ikinci nedeninin de reklamların çocuklarını olumsuz yönde etkilediğini düşündükleri sonucuna varılmıștır. Gümüş (2013) ise ebeveynlerin tamamına yakının (ort. 4,58) çocuklarının reklamlarda izlediği ürünleri satın almaları için kendilerine baskı yaptıklarını, yine büyük çoğunluğunun (ort. 4,01) gıda reklamlarının çocuklarının beslenme alışkanlığı açısından sorunlar meydana getirdiğini belirtmiştir.

$\mathrm{Bu}$ araştırma bulgularından yola çıkılarak ebeveynlerin çocuklara yönelik televizyon reklamlarının çocuklar üzerinde olumsuz etkileri olduğuna yönelik algılarının, tutumları, çocukları ile reklam içerikleri hakkında konuşmaları ve çocuklarına uyguladıkları televizyon izleme kontrolü üzerinde anlamlı bir etkisi olacağı düşünülmüş ve aşağıdaki hipotezler oluşturulmuştur:

H4: Televizyon reklamlarının olumsuz etkisi olduğuna dair ebeveyn algılarının tutumları üzerinde anlamlı bir etkisi vardır.

H5: Televizyon reklamlarının olumsuz etkisi olduğuna dair ebeveyn algılarının çocukları ile reklam içerikleri hakkında konuşmaları üzerinde anlamlı bir etkisi vardır.

H6: Televizyon reklamlarının olumsuz etkisi olduğuna dair ebeveyn algılarının çocuklarına uyguladıkları televizyon izleme kontrolü üzerinde anlamlı bir etkisi vardır.

\section{Tutum}

Teorik açıdan bakıldığında ebeveynlerin, çocuklarının çok fazla etkili televizyon reklam mesajına maruz kaldığına inandıkları tespit edilmiştir. Çocuklarının savunmasızlığının farkında olarak ebeveynler kendilerini sorumlu görmekte ve çocuklarının televizyon izleme davranışları üzerinde aktif ve kısıtlayıcı bir şekilde aracılık etmektedir. Genel olarak ebeveynler, çocuklara yönelik televizyon reklamcılığına ilişkin olumsuz tutumlara sahiptir ve çocuklarının, çoğu zaman gerçekten ihtiyaç duymadıkları ürünleri satın aldırma baskısını hissetmektedir (Nefat \& Dujmović, 2012).

Ebeveynlerin reklamların çocukları üzerinde yol açtığı eksik veya yanlış algıları kırabilmesi ve çocuklarını doğru olana yönlendirebilmesi güçleşebilmektedir. Bu noktada 
en büyük görev belki de yine kendilerine düşmektedir. Çocukların boş zamanlarının büyük bir kısmının televizyon karşısında geçirdikleri göz önüne alındığında, ebeveynlere düşen ilk görev öncelikle çocuklarını televizyon seyrederken yalnız ve savunmasız bırakmamak, mümkün olduğunca çocuklarına eşlik etmek olacaktır. Bir yandan reklamların içeriği ile ilgili çocuklarıyla konuşmalı ve görüşlerini onlarla paylaşmalı, diğer yandan da onları okumaya teşvik etmeli ve televizyon izlemelerine belli ölçülerde sinırlamalar getirmelidirler (Engin, 2013). Zira ebeveynlerin tutumları, çocuklarının reklama yönelik tutumlarını yansıtmaktadır. Ebeveynler iyi örgütlenirlerse mevzuat üzerinde dahi etkisini gösterebilecek önemli bir faktördür (Nefat \& Dujmović, 2012). Diğer yandan reklama yönelik olumsuz tutumların, sonunda bireysel reklamlara ve hatta reklamı yapılan markalara yönelik olumsuz tutumlara dönüşmesi de olasıdır (Chan \& McNeal, 2002). Bu nedenle ebeveynlerin çocuklara yönelik tutum ve davranışlarını anlamak çocuk izleyicilere etkili bir biçimde ulaşmak isteyen reklam verenler için de son derece önemlidir.

Mukherji (2005) araştırmasında, Hindistan'daki annelerin televizyon reklamcılığına (ortalama değer 2,88) ve çocuklara yönelik reklamcılığa $(2,19)$ karşı Japonya'daki (ortalama değerler 3,55, 3,28 ve 3,41) ve ABD'deki (ortalama değerler 4,05, 3,86 ve 4,07) annelere göre daha az olumsuz tutum sergilediğini ve çocuklarını daha az denetlediğini $(3,08)$ tespit etmiștir. Morley, Chapman, Mehta, King, Swinburn ve Wakefield (2008) yaptığı araştırmada ise, ankete katılan ebeveynlerin yaklaşık üçte ikisi, çocuklarının televizyon izleme saatlerinde maruz kaldıkları sağlıksız gıda ürünlerinin reklamlarından endișe duymaktadır. Ayrıca popüler kişiliklerin veya karakterlerin kullanımı, ürünlerle birlikte verilen ücretsiz oyuncaklar veya hediyeler konusunda da endișeli bir tutum sergiledikleri de belirtilmiştir. Chan ve McNeal (2002) tarafından yapılan bir başka araștırmada, Çinli ebeveynlerin genel olarak televizyon reklamcılığına ve özel olarak çocuklara yönelik reklamlara karşı olumsuz tutumlara sahip oldukları belirtilmiş, söz konusu olumsuz tutumların da esas olarak reklamın aldatıcı ve sinir bozucu olduğu algısından kaynaklandığı ortaya çıkmıştır. Ayrıca aynı araştırma sonuçlarına göre ebeveynlerin çocuk reklamlarına yönelik negatif tutumları ile televizyon izleme kontrolü ve reklamlar hakkında tartışmaları arasında herhangi bir ilişki yoktur. Dens ve diğerleri (2007) tarafından yapılan araştırmaya göre ebeveynlerin çocuklara yönelik yiyecek reklamlarına ilişkin olumsuz tutumlarının çocuklarının televizyon izlemelerini kısıtlamaları üzerinde bir etkisi bulunmamıştır.

$\mathrm{Bu}$ araştırma bulgularından hareketle, ebeveynlerin çocuklara yönelik televizyon reklamlarına yönelik tutumlarının, çocukları ile reklam içerikleri hakkında konuşmalarına ve çocuklarına televizyon izleme kontrolü uygulamalarına yol açabileceği düşünülmüş ve aşağıdaki hipotezler geliştirilmiştir:

H7: Televizyon reklamlarına yönelik ebeveyn tutumlarının çocukları ile reklam içerikleri hakkında konuşmaları üzerinde anlamlı bir etkisi vardır.

H8: Televizyon reklamlarına yönelik ebeveyn tutumlarının çocuklarına uyguladıkları televizyon izleme kontrolü üzerinde anlamlı bir etkisi vardır.

\section{Ebeveyn Arabuluculuğu}

Bilinçsiz ve aşırı tüketim ne yazık ki çocuklarda doyumsuzluğa neden olabilmektedir. Çocuklarının doyumsuz ve mutsuz birer birey olarak yetişmemeleri için ebeveynlerin birtakım tedbirler alması elzemdir. Televizyonun davranışların şekillenmesine yönelik kritik etkisi de göz önünde bulundurulduğunda, çocukların televizyon izleme tercih ve 
sürelerinin kontrolü üzerinde ebeveynlere ciddi sorumluluklar yüklenmektedir (Dal \& Dal, 2015). Örneğin ebeveyn çocuğuna, televizyonda reklamı yapılan ürüne gerçekten ihtiyacı olup olmadığı veya sağlıklı bir ürün olup olmadığına ilișkin bilgi vermeli, reklamın içeriği hakkında onunla tartışmalı ve televizyon izleme davranışı üzerinde birtakım kontroller uygulamalıdır.

Literatürde, ebeveyn arabuluculuğuna ilişkin sınırlı sayıda araştırmaya rastlanmış olup araştırmaların sonuçları, farklı düzeylerde de olsa tüm ebeveynlerin çocukların televizyon izleme alışkanlıklarına yönelik birtakım düzenlemeler yaptıkları yönündedir. Örneğin, Chan ve McNeal (2002) tarafından yapılan araștırmada ebeveynlerin \% 98'inin televizyon izlemenin içeriği ve süresi üzerinde bir miktar kontrol uyguladığını, çocukları ile televizyon reklamlarını birlikte izleme ve tartışma düzeyinin düşük olmasına rağmen, çocuklarının reklama karşı tutumlarında büyük etkiye sahip oldukları sonucu elde edilmiştir. Rose ve diğerlerinin (1998) Amerikalı ve Japonyalı anneler üzerinde yaptığı araştırma sonuçları incelendiğinde, Amerikalı annelerin Japonyalı annelere göre çocuklara yönelik televizyon reklamlarına karşı daha olumsuz tutumlara sahip oldukları ve çocuklarının televizyon izleme sürecini kontrol ederek ve onlarla reklamlar hakkında tartışarak çocuklarının reklama maruz kalmasına aktif olarak aracılık ettikleri tespit edilmiştir. Araştırmada ayrıca Japon annelerin çocuklara yönelik reklamlara karşı daha iyimser bir bakış açısına sahip olduğu ve çocuklarının televizyon izlemesini daha az kontrol ettikleri belirtilmiştir. Nefat ve Dujmović'in (2012) yaptığı araștırmada ise, ebeveynlerin büyük bir kısmının (ortalama değer 3,72) çocuklarının televizyon izleme sürelerini kontrol ettikleri ve çocuklarıyla reklamların içeriği hakkında konuştukları belirtilmiștir (ortalama değer 3,93). Yine, Dens ve diğerleri (2007) tarafından yapılan çalışmaya göre neredeyse tüm ebeveynler, çocuklarının televizyon izleme davranışı üzerinde en azından bir miktar etkide bulunduklarını belirtmişlerdir.

Sonuç olarak ebeveynler, reklamlar hakkında çocuklarıyla etkili iletişim kurduğu takdirde, televizyon reklamlarının istenmeyen etkilerini yok etmiş veya azaltmış olacaklardır. Ancak reklam verenlerin ve reklam ajanslarının da çocukların fiziksel, ruhsal ve toplumsal sağlıklarını daha çok dikkate alarak mesajlarını vermeleri gerekmektedir (Dal \& Dal, 2015). Ebeveynler, çocuklarının televizyon izleme süresi ve içeriği üzerinde kontrolü ele alarak televizyon içeriğinin bekçisi olarak hizmet etmektedir. Bu nedenle, çocukları hedefleyen reklam kampanyalarının, mesajlarının çocuklara ulaşmasından önce kapı bekçilerinin yeşil ışığını alması gerekmektedir (Chan \& McNeal, 2002).

\section{Metodoloji}

Bu çalışmada ebeveynlerin çocuklara yönelik televizyon reklamlarına ilişkin algılarının tutumları ve arabuluculukları üzerindeki etkilerinin araştırılması amaçlanmıştır. Bu amaç doğrultusunda yapılan literatür taraması dikkate alınarak ebeveynlerin çocuklara yönelik televizyon reklamlarına ilişkin algılarının, tutumlarını ve arabuluculuklarını etkileyeceği öngörülmektedir. Buna göre, araştırma modeli Şekil 1'deki gibidir: 


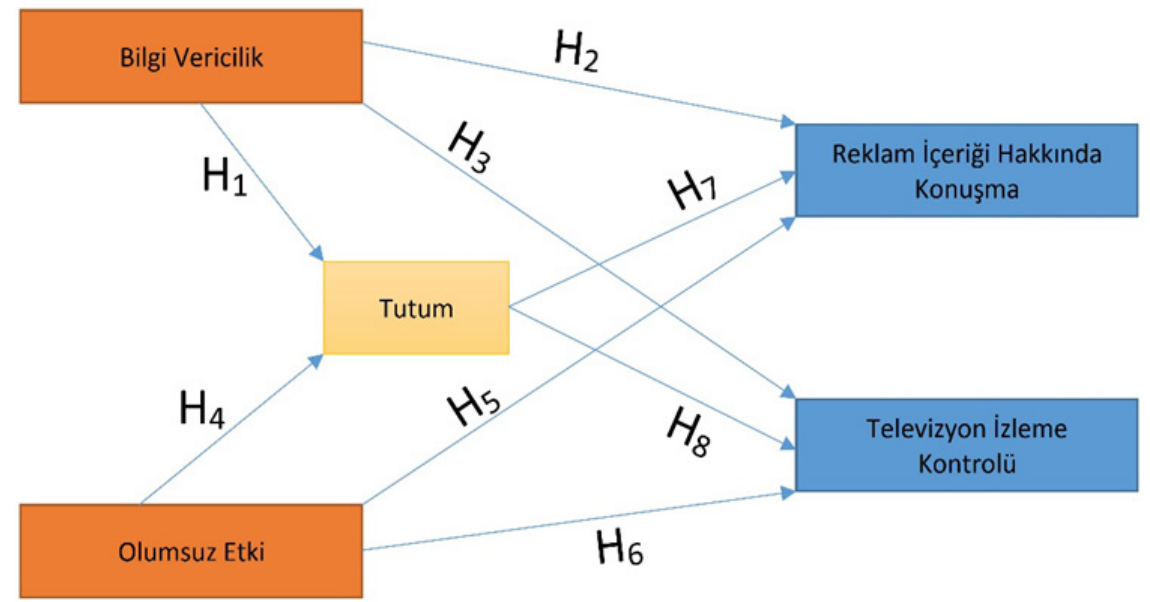

Şekil 1. Araştırma Modeli

Araştırmanın ana kütlesini, Kocaeli ili Gölcük ilçesindeki ilköğretim okullarında eğitim gören 8-15 yaş arası çocuğu olan ebeveynler oluşturmaktadır. Zaman ve maliyet kısıtlarından dolayı, araștırmanın katılımcılarının belirlenmesinde tesadüfi olmayan örnekleme yöntemlerinden kolayda örnekleme yöntemi kullanılmış ve araştırma verileri yüz yüze anket yöntemi ile toplanmıştır. Anket çalışması 2019-2020 eğitim öğretim yılı içerisinde Kocaeli ili Gölcük ilçesindeki iki İlköğretim okulunun velileri ile yapılmıştır. Ebeveynlerden toplanan geçerli veri sayısı 247'dir. Hair, Anderson, Babin ve Black'a (2010) göre, yapısal eşitlik modeli için uygun örneklem sayısı 100 ile 400 arasında olmalıdır. Ayrıca, çeşitli araştırmacılar (Kline, 2016; Loehlin, 2004). Yapısal Eşitlik Modellemesi için örnek hacminin en az 200 olması gerektiğini ifade etmektedir. Buna göre, örneklem büyüklüğünün 247 olması analiz için yeterli bulunmuştur.

Ebeveyn algılarını ölçmek için Young ve diğerlerinin (2003), tutumları için Wolin, Korgaonkar ve Lund'un (2002), ebeveyn arabuluculuğu için ise Mukherji'nin (2005) çalışmalarında yer alan ölçekler kullanılmıştır. Anketteki tüm ifadeler "Kesinlikle Katılmıyorum" ve "Kesinlikle Katılıyorum" aralığında değişen 5'li likert ölçeği ile ölçülmüştür. Bunun yanında, ankette katılımcıların demografik özelliklerini tespit etmek için yaş, cinsiyet, eğitim ve gelir düzeyi gibi sorulara da yer verilmiştir. Araştırma amacı ve modeline göre geliştirilen hipotezler SPSS ve AMOS 24 istatistik paket programları ile test edilmiştir.

\section{Etik Kurul İzni}

Yalova Üniversitesi Sosyal Bilimler Etik Kurulu 16/05/2019 tarih ve 93772138 numaralı toplantısında alınan karar çerçevesinde çalışma etik açıdan bir sakınca içermemektedir.

\section{Bulgular}

Araştırmaya katılan ebeveynlerin sosyo-demografik özelliklerinin yer aldığı Tablo 1'de görüldüğü gibi, katılımcıların \%51,0'ini kadınlar, \%49,0'ını erkekler oluşturmaktadır. Bununla birlikte katılımcıların 30-39 (\%47,8) ve 40-49 (\%44,5) yaş aralığında yoğunlaştığı, çoğunluğunun ortaokul mezunu olduğu $(\% 31,2)$, aylık gelirlerinin 20044,000 TL aralığında, büyük çoğunluğunun ise çalışmayan $(\% 34,0)$ ve özel sektör çalışanı $(\% 24,3)$ olduğu görülmektedir. Araştırmaya katılan ebeveynlerin çocuklarının yaşlarının büyük çoğunluğunun $11(\% 25,5)$ ve $12(\% 25,1)$ yaş aralığında olduğu ve yine büyük bir kısmının günde $1-2$ saat $(\% 40,1)$ televizyon izlediği görülmektedir. 
Tablo 1. Ebeveynlerin Sosyo-Demografik Özellikleri ( $n=247)$

\begin{tabular}{|c|c|c|c|c|c|}
\hline Cinsiyet & $\mathbf{f}$ & $\%$ & Meslek & $\mathbf{f}$ & $\%$ \\
\hline Kadın & 126 & 51,0 & Özel sektör & 60 & 24,3 \\
\hline Erkek & 121 & 49,0 & Kamu sektörü & 33 & 13,4 \\
\hline Yaş & $\mathbf{f}$ & $\%$ & Serbest meslek & 52 & 21,1 \\
\hline $20-29$ & 10 & 4,0 & Çalışmıyor & 84 & 34,0 \\
\hline $30-39$ & 118 & 47,8 & Diğer & 18 & 7,3 \\
\hline $40-49$ & 110 & 44,5 & Çocuk Yaşı & $f$ & $\%$ \\
\hline $50-59$ & 7 & 2,8 & 8 & 1 & 0,4 \\
\hline $70+$ & 2 & 0,8 & 9 & 2 & 0,8 \\
\hline Eğitim Düzeyi & $\mathbf{f}$ & $\%$ & 10 & 27 & 10,9 \\
\hline İlkokul mezunu & 61 & 24,7 & 11 & 63 & 25,5 \\
\hline Ortaokul mezunu & 77 & 31,2 & 12 & 62 & 25,1 \\
\hline Lise mezunu & 53 & 21,5 & 13 & 46 & 18,6 \\
\hline Ön Lisans mezunu & 24 & 9,7 & 14 & 42 & 17,0 \\
\hline Lisans mezunu & 26 & 10,5 & 15 & 4 & 1,6 \\
\hline Yüksek Lisans mezunu & 6 & 2,4 & Televizyon İzleme Süresi & $f$ & $\%$ \\
\hline Aylık Aile Geliri & $\mathbf{f}$ & $\%$ & 1 saatten az & 47 & 19,0 \\
\hline 2000 TL'den az & 34 & 13,8 & 1-2 saat & 99 & 40,1 \\
\hline $2001-4000 \mathrm{TL}$ & 127 & 51,4 & 2-3 saat & 75 & 30,4 \\
\hline 4001-6000 TL & 67 & 27,1 & 3 saatten fazla & 26 & 10,5 \\
\hline $6001-8000 \mathrm{TL}$ & 6 & 2,4 & & & \\
\hline $8001-10000 \mathrm{TL}$ & 8 & 3,2 & & & \\
\hline $10001 \mathrm{TL}+$ & 5 & 2,0 & & & \\
\hline
\end{tabular}

Araştırmada kullanılan ölçeklerin güvenilirlik analizlerinde, araştırmacıların yaygın şekilde kullandığı “Cronbach's Alpha” katsayısından yararlanılmıștır. Cronbach's Alfa katsayısının 0.70'den küçük olması, içsel tutarlılığın "düşük" olduğunu göstermektedir (Hair, Wolfinbarger, Bush, \& Ortinau, 2009). Araştırmada kullanılan ölçeklerin Cronbach's Alfa katsayıları Tablo 2'de sunulmuştur.

Tablo 2. Ölçeklerin Cronbach's Alfa Katsayıları

\begin{tabular}{|l|c|c|}
\hline Boyut & Değişken Sayısı & Cronbach's Alpha \\
\hline Bilgi Vericilik & 3 & 0,765 \\
\hline Olumsuz etki & 4 & 0,808 \\
\hline Çocuk Reklamlarına Yönelik Tutum & 3 & 0,799 \\
\hline Reklam İçeriği Hakkında Konuşma & 2 & 0,711 \\
\hline Televizyon İzleme Kontrolü & 3 & 0,803 \\
\hline
\end{tabular}

Tablo 2'de görüldüğü üzere bilgi vericilik boyutunun güvenilirlik katsayısı 0,765 , reklamların olumsuz etkisine yönelik algı boyutunun güvenilirlik katsayısı 0,808, tutum ölçeğinin güvenilirlik katsayısı 0,799, reklam içeriği hakkında konuşma boyutunun güvenilirlik katsayısı 0,711 ve Televizyon İzleme Kontrolü boyutunun 0,803’dür.

Araştırmaya katılan ebeveynlerin çocuklara yönelik televizyon reklamlarına ilişkin algıları, tutum ve arabuluculukları ile ilgili tanımlayıcı istatistikler Tablo 3'de sunulmuştur. 
Tablo 3. Ebeveynlerin Çocuklara Yönelik Televizyon Reklamlarına İlișkin Algıları, Tutum ve Arabuluculukları ile İlgili Tanımlayıcı Ístatistikler

\begin{tabular}{|c|c|c|}
\hline İfade & Ortalama & Standart Sapma \\
\hline \multicolumn{3}{|l|}{ Bilgi Vericilik } \\
\hline Çocuklara yönelik televizyon reklamları genelde çok bilgi vericidir. & 2,1417 & 1,06695 \\
\hline $\begin{array}{l}\text { Çocuklara yönelik televizyon reklamları tüketiciler } \\
\text { için değerli bir bilgi kaynağıdır. }\end{array}$ & 2,3522 & 1,17279 \\
\hline $\begin{array}{l}5 \text { yaşından büyük çocukların çoğu çocuklara yönelik } \\
\text { televizyon reklamlarının amacını anlar. }\end{array}$ & 2,7449 & 1,15282 \\
\hline \multicolumn{3}{|l|}{ Olumsuz Etki } \\
\hline $\begin{array}{l}\text { Çocuklara yönelik televizyon reklamları, çocukların bir şeyler satın } \\
\text { aldırmak için ebeveynleri üzerinde baskı yapmasına neden olmaktadır. }\end{array}$ & 4,2713 & 0,96446 \\
\hline $\begin{array}{l}\text { Çocuklar ne kadar çok reklam izlerse reklamı } \\
\text { yapılan ürünleri o kadar çok isterler. }\end{array}$ & 4,1822 & 0,99348 \\
\hline $\begin{array}{l}\text { Çocuklar genellikle televizyon reklamlarında } \\
\text { gördükleri yiyecekleri talep ederler. }\end{array}$ & 4,1579 & 0,89906 \\
\hline $\begin{array}{l}\text { Çocuklara yönelik gıda reklamları, çocukların beslenme } \\
\text { düzeni üzerinde başlıca etkiye sahiptir. }\end{array}$ & 3,8785 & 1,06755 \\
\hline \multicolumn{3}{|l|}{ Tutum } \\
\hline Çocuklara yönelik televizyon reklamları çok kötüdür. & 3,1457 & 1,12754 \\
\hline Çocuklara yönelik televizyon reklamlarını hiç beğenmiyorum. & 3,2955 & 1,10694 \\
\hline Çocuklara yönelik televizyon reklamları hiç gerekli değildir. & 3,3482 & 1,17918 \\
\hline \multicolumn{3}{|l|}{ Televizyon İçeriği Hakkında Konuşma } \\
\hline $\begin{array}{l}\text { Çocuğuma çocuklara yönelik televizyon reklamlarını } \\
\text { beğenip beğenmediğini sorarım. }\end{array}$ & 3,0202 & 1,24433 \\
\hline $\begin{array}{l}\text { Çocuğumla çocuklara yönelik televizyon } \\
\text { reklamlarını neden sevdiğini tartışııım. }\end{array}$ & 3,1538 & 1,25936 \\
\hline \multicolumn{3}{|l|}{ Televizyon İzleme Kontrolü } \\
\hline $\begin{array}{l}\text { Çocuğumun televizyonda hangi programları } \\
\text { izleyeceği konusunda kısıtlamalar getiririm. }\end{array}$ & 4,0445 & 1,03694 \\
\hline Çocuğumun ne zaman televizyon izleyebileceğine dair kısıtlamalar getiririm. & 3,9514 & 1,05039 \\
\hline $\begin{array}{l}\text { Çocuğumun günde kaç saat televizyon izleyebileceği } \\
\text { konusunda kısıtlamalar getiririm. }\end{array}$ & 3,8866 & 1,02969 \\
\hline
\end{tabular}

Tablo 3 incelendiğinde araştırmaya katılan ebeveynlerin yarısından azı çocuklara yönelik reklamların bilgi verici olduğunu düşünmektedir $(2,14$ ve 2,35). Bu sonuç konuyla ilgili daha önce yapılan çalışmalardan elde edilen sonuçları desteklememektedir (Dağlı \& Hacıbektaşoğlu, 2015; Çakır, 2019; Young ve diğerleri, 2003).

Olumsuz etki faktörüne ait ifadelere bakıldığında ebeveynlerin neredeyse tamamı çocuklara yönelik televizyon reklamlarının, çocuklarının bir şeyler satın aldırmak için üzerlerinde baskı yapmalarına neden olduğunu $(4,27)$, çocuklarının ne kadar çok reklam izlerse reklamı yapılan ürünleri o kadar çok istediğini $(4,18)$, çocuklarının genellikle televizyon reklamlarında gördükleri yiyecekleri talep ettiğini $(4,15)$ ve ebeveynlerin bir çoğunun da gıda reklamlarının, çocuklarının beslenme düzeni üzerinde başlıca etkiye sahip olduğunu belirtmiştir $(3,87)$. Araștırmadan elde edilen sonuçlar literatürden elde edilen araştırma sonuçları ile paralellik göstermiştir (Chan \& McNeal, 2002; Dağlı \& Hacıbektaşoğlu, 2015; Doğan, 2003; Gümüş, 2013; Karaca ve diğerleri, 2007; Nefat \& Dujmović, 2012; Young ve diğerleri, 2003). Ancak Dens ve diğerleri (2007) tarafından yapılan araştırma bulguları incelendiğinde pek çok ebeveynin, çocuklara yönelik televizyon reklamlarının çocuklarının yeme alışkanlıklarını etkilediğini düşünürken diğer araştırmaların aksine ebeveynlerin yalnızca \%20'sinin reklamların çocukları 
üzerinde etkisi olduğunu düşündükleri görülmüş ve elde edilen araştırma sonuçlarını desteklememiştir.

Tutum faktörü ile ilgili ifadelere verilen yanıtların ortalama değerleri incelendiğinde yine araştırmaya katılan ebeveynlerin büyük bir kısmının $(3,14,3,29$ ve 3,34) çocuklara yönelik televizyon reklamlarına ilişkin olumsuz tutum sergilediği görülmektedir. Söz konusu sonuçlar daha önce yapılan çalışmaları desteklemektedir (Chan \& McNeal, 2002; Dens, Pelsmacker, \& Eagle, 2007; Morley, ve diğerleri, 2008; Mukherji, 2005). Son olarak ebeveyn arabuluculuğu olarak isimlendirilen faktöre ait ifadeler incelendiğinde ebeveynlerin büyük çoğunluğunun çocuklara yönelik televizyon reklamlarının içeriği hakkında çocukları ile konuştukları $(3,02,3,15)$ ve televizyonda hangi programları, ne zaman ve ne kadar süre izleyecekleri hususunda bir takım kısıtlamalar getirdikleri görülmektedir $(4,04,3,95,3,88)$. Bu sonuçlar da daha önce yapılan araştırmaları desteklemektedir (Chan \& McNeal, 2002; Dens, Pelsmacker, \& Eagle, 2007; Nefat \& Dujmović, 2012; Rose ve diğerleri, 1998).

\section{1. Ölçüm Modeli}

Araştırma modelinin analiz edilmesinde Yapısal Eşitlik Modeli (YEM) kullanılmıştır. Öncelikle, ölçüm modeli oluşturularak doğrulayıcı faktör analizi uygulanmıştır. Uygun ölçüm modelinin belirlenmesinin ardından, oluşturulan yapısal model yol analizi ile test edilmiştir.

Çalışmada ölçüm modeli doğrulayıcı faktör analizi ile test edilmiş, uygun yapı elde edilinceye kadar analiz tekrarlanmıştır. Ölçüm modelinin değerlendirilmesinde; maddelerin faktör yükünün 0,50'nin üzerinde olmasına (Hair, Black, Babin, \& Anderson, 2014) ve model uyum indekslerinin standart uyum sınırları arasında kalmasına dikkat edilmiștir (Hair ve diğerleri, 2014; Schermelleh-Engel, Moosbrugger, \& Müller, 2003). Ölçüm modelinin geçerliliği ve güvenilirliği ayrım geçerliliği ve uyum geçerliliği analizleri ile ölçülmüştür. Modelin uyum geçerliliğinde yapı güvenilirliğinin (CR) 0.70'in üzerinde, ortalama açıklanan varyansın (AVE) 0.50 ve üzerinde olması (Fornell \& Larcker, 1981) kriterleri dikkate alınmıştır. Ölçüm modeline uygulanan doğrulayıcı faktör analizi sonuçları Tablo 4'deki gibidir.

Tablo 4. Doğrulayıcı Faktör Analizi Sonuçları ve Yapı Güvenilirliği Değerleri

\begin{tabular}{|c|c|c|c|}
\hline Boyut & Madde & Standardize Edilmiş Faktör Yükleri & Yapı Güvenilirliği \\
\hline \multirow{4}{*}{ Olumsuz Etki } & 21 & 0,609 & \multirow{4}{*}{0,820} \\
\hline & 20 & 0,816 & \\
\hline & 19 & 0,790 & \\
\hline & 18 & 0,692 & \\
\hline \multirow{3}{*}{ Tutum } & 1 & 0,715 & \multirow{3}{*}{0,800} \\
\hline & 2 & 0,749 & \\
\hline & 3 & 0,803 & \\
\hline \multirow{2}{*}{$\begin{array}{l}\text { Televizyon içeriği } \\
\text { hakkında konuşma }\end{array}$} & 2 & 0,779 & \multirow{2}{*}{0,713} \\
\hline & 3 & 0,708 & \\
\hline \multirow{3}{*}{$\begin{array}{l}\text { Televizyon izleme } \\
\text { kontrolü }\end{array}$} & 4 & 0,694 & \multirow{3}{*}{0,811} \\
\hline & 5 & 0,874 & \\
\hline & 6 & 0,727 & \\
\hline \multirow{3}{*}{ Bilgi vericilik } & 16 & 0,588 & \multirow{3}{*}{0,773} \\
\hline & 15 & 0,790 & \\
\hline & 14 & 0,798 & \\
\hline
\end{tabular}


Tablo 4'deki değerler incelendiğinde, standartlaştırılmış faktör yüklerinin 0,50'nin üzerinde olduğu görülmektedir. Ayrıca CR değerleri, 0.70'in üzerindedir. Boyutlar arasındaki korelasyonu gösteren korelasyon matrisine ilişkin sonuçlar Tablo 5'de gösterilmiştir.

Tablo 5. AVE Değerleri ve Korelasyon Matrisi

\begin{tabular}{|l|c|c|c|c|c|c|c|}
\hline Boyut & CR & AVE & konuşma & tutum & kontrol & olumsuz etki & bilgi vericilik \\
\hline konuşma & 0,713 & 0,554 & 0,744 & & & & \\
\hline tutum & 0,800 & 0,572 & 0,169 & 0,757 & & & \\
\hline kontrol & 0,811 & 0,591 & 0,351 & 0,211 & 0,769 & & \\
\hline olumsuz etki & 0,820 & 0,535 & $-0,024$ & 0,269 & 0,280 & 0,731 & \\
\hline bilgi vericilik & 0,773 & 0,536 & 0,128 & $-0,383$ & $-0,091$ & $-0,041$ & 0,732 \\
\hline
\end{tabular}

Tablo 5 incelendiğinde, örtük değişkenler arasında yüksek korelasyon olmadığı ve AVE değerlerinin de 0.50'nin üzerinde olduğu görülmektedir. AVE değerlerinin karekökleri ile değişkenler arasındaki korelasyonlar karşılaştırılarak ölçüm modelinin ayırıcı geçerliliğinin sağlandığı tespit edilmiştir. Buna göre, ölçüm modelinin uygun olduğu sonucuna ulaşılmıștır.

Ölçüm modelinin uyumu literatürde yaygın olarak kullanılan x2/sd, RMSEA (Yaklaşık Hataların Ortalama Karekökü), CFI (Karşılaştırmalı Uyum İndeksi) GFI (İyilik Uyum İndeksi), AGFI (Düzeltilmiş İyilik Uyum İndeksi), TLI (Tucker-Lewis İndeksi), IFI (Artırmalı Uyum İndeksi) uyum değerleri ile değerlendirilmiştir. Ölçüm modeline ilişkin uyum ölçütleri ve hesaplanan uyum değerlerinin yer aldığı Tablo 6 değerlendirildiğinde, modelin iyi seviyede uyum gösterdiği sunucuna varılmıştır.

Tablo 6. Ölçüm Modelinin Uyum Değerleri ve Standart Uyum Değerleri

\begin{tabular}{|l|l|l|l|l|}
\hline Uyum Ölçüleri & İyi Uyum Değerleri & $\begin{array}{l}\text { Kabul Edilebilir } \\
\text { Uyum Değerleri }\end{array}$ & $\begin{array}{l}\text { Ulaşılan Uyum } \\
\text { Degerleri }\end{array}$ & Uyum Durumu \\
\hline$\chi^{2} / \mathrm{df}$ & $\leq 3$ & $\leq 5$ & 1,471 & İyi Uyum \\
\hline GFI & $\geq 0,9$ & $\geq 0,8$ & 0,941 & İi Uyum \\
\hline AGFI & $\geq 0,9$ & $\geq 0,8$ & 0,911 & İyi Uyum \\
\hline CFI & $\geq 0,95$ & $\geq 0,9$ & 0,967 & İyi Uyum \\
\hline TLI & $\geq 0,95$ & $\geq 0,9$ & 0,957 & İyi Uyum \\
\hline IFI & $\geq 0,95$ & $\geq 0,9$ & 0,968 & İyi Uyum \\
\hline RMSEA & $\leq 0,05$ & $\leq 0,08$ & 0,045 & İyi Uyum \\
\hline
\end{tabular}

\subsection{Yapısal Model}

Ölçüm modeli doğrulandıktan sonra, yapısal model, yol analizi (PA) kullanılarak analiz edilmiştir. Modelde yer alan yollar, bunlara ait standartlaştırılmış regresyon katsayıları, $\mathrm{t}$ değerleri ve anlamlılık düzeyleri Tablo 7'deki gibidir.

Tablo 7. Yapısal Analiz Sonuçları

\begin{tabular}{|l|l|l|l|l|}
\hline Yollar & $\begin{array}{l}\text { Standart Regresyon } \\
\text { Ağırlıkları }\end{array}$ & $\begin{array}{l}\text { Standart } \\
\text { Hata }\end{array}$ & t değeri & P değeri \\
\hline Bilgi Vericilik $\rightarrow$ Tutum & 0,452 & 0,104 & 4,326 & $* \star *$ \\
\hline $\begin{array}{l}\text { Bilgi Vericilik } \rightarrow \text { Reklam içeriği } \\
\text { hakkında konuşma }\end{array}$ & 0,311 & 0,142 & 2,181 & 0,029 \\
\hline Bilgi vericilik $\rightarrow$ Televizyon izleme kontrolü & 0,001 & 0,090 & 0,010 & 0,992 \\
\hline Olumsuz Etki $\rightarrow$ Tutum & $-0,325$ & 0,100 & $-3,240$ & 0,001 \\
\hline $\begin{array}{l}\text { Olumsuz Etki } \rightarrow \text { Reklam içeriği } \\
\text { hakkında konuşma }\end{array}$ & $-0,104$ & 0,125 & $-0,829$ & 0,407 \\
\hline
\end{tabular}




\begin{tabular}{|l|l|l|l|l|}
\hline Yollar & $\begin{array}{l}\text { Standart Regresyon } \\
\text { Ağırlıkları }\end{array}$ & $\begin{array}{l}\text { Standart } \\
\text { Hata }\end{array}$ & t değeri & P değeri \\
\hline Olumsuz Etki $\rightarrow$ Televizyon izleme kontrolü & 0,255 & 0,093 & 2,734 & 0,006 \\
\hline Tutum $\rightarrow$ Reklam içeriği hakkında konuşma & $-0,340$ & 0,131 & $-2,593$ & 0,010 \\
\hline Tutum $\rightarrow$ Televizyon izleme kontrolü & $-0,147$ & 0,081 & $-1,810$ & 0,070 \\
\hline \multicolumn{2}{|l}{ Model Uyum İndeksi: x²/sd = 1.670; RMSEA= $0.053 ;$ GFI = 0.932; CFI =0.953; IFI=0.954 } \\
\hline
\end{tabular}

Sonuçlar incelendiğinde, t-değerleri \pm 1.96 sinırından büyük olan H1, H2, H4, H6 ve H7 hipotezleri kabul edilmekte H3, H5 ve H8 reddedilmektedir. Yapısal modelin uyum değerleri de, iyi seviyede uyumu göstermektedir. Tablo 8'de araştırma modeline ilişkin oluşturulan hipotez sonuçları sunulmuştur.

Tablo 8. Araştırma Modeline İlişkin Hipotez Sonuçları

\begin{tabular}{|c|c|}
\hline Hipotezler & Sonuç \\
\hline $\begin{array}{l}\text { H1: Televizyon reklamlarının bilgi verici olduğuna dair ebeveyn algılarının } \\
\text { tutumları üzerinde anlamlı bir etkisi vardır. (Bilgi Vericilik } \rightarrow \text { Tutum) }\end{array}$ & Kabul \\
\hline $\begin{array}{l}\text { H2: Televizyon reklamlarının bilgi verici olduğuna dair ebeveyn algılarının } \\
\text { çocukları ile reklam içerikleri hakkında konuşmaları üzerinde anlamlı bir } \\
\text { etkisi vardır. (Bilgi Vericilik } \rightarrow \text { Reklam içeriği hakkında konuşma) }\end{array}$ & Kabul \\
\hline $\begin{array}{l}\text { H3: Televizyon reklamlarının bilgi verici olduğuna dair ebeveyn algılarının } \\
\text { çocuklarına uyguladıkları televizyon izleme kontrolü üzerinde anlamlı } \\
\text { bir etkisi vardır. (Bilgi vericilik } \rightarrow \text { Televizyon izleme kontrolü) }\end{array}$ & Red \\
\hline $\begin{array}{l}\text { H4: Televizyon reklamlarının olumsuz etkisi olduğuna dair ebeveyn algılarının } \\
\text { tutumları üzerinde anlamlı bir etkisi vardır. (Olumsuz Etki } \rightarrow \text { Tutum) }\end{array}$ & Kabul \\
\hline $\begin{array}{l}\text { H5: Televizyon reklamlarının olumsuz etkisi olduğuna dair ebeveyn algılarının } \\
\text { çocukları ile reklam içerikleri hakkında konuşma üzerinde anlamlı bir } \\
\text { etkisi vardır. (Olumsuz Etki } \rightarrow \text { Reklam içeriği hakkında konuşma) }\end{array}$ & Red \\
\hline $\begin{array}{l}\text { H6: Televizyon reklamlarının olumsuz etkisi olduğuna dair ebeveyn } \\
\text { algılarının çocuklarına uyguladıkları televizyon izleme kontrolü üzerinde } \\
\text { anlamlı bir etkisi vardır. (Olumsuz Etki } \rightarrow \text { Televizyon izleme kontrolü) }\end{array}$ & Kabul \\
\hline $\begin{array}{l}\text { H7: Televizyon reklamlarına yönelik ebeveyn tutumlarının çocukları } \\
\text { ile reklam içerikleri hakkında konuşmaları üzerinde anlamlı bir etkisi } \\
\text { vardır. (Tutum } \rightarrow \text { Reklam içeriği hakkında konuşma) }\end{array}$ & Kabul \\
\hline $\begin{array}{l}\text { H8: Televizyon reklamlarına yönelik ebeveyn tutumlarının çocuklarına } \\
\text { uyguladıkları televizyon izleme kontrolü üzerinde anlamlı bir } \\
\text { etkisi vardır. (Tutum } \rightarrow \text { Televizyon izleme kontrolü) }\end{array}$ & Red \\
\hline
\end{tabular}

\section{Sonuç ve Değerlendirme}

$\mathrm{Bu}$ çalışma kapsamında ilköğretim çağında çocuğu olan ebeveynler üzerinde bir araştırma yapılmış olup çocuklara yönelik televizyon reklamlarına ilişkin tutum ve ebeveyn arabuluculuğunun oluşumunda algıların etkisi incelenmiştir. $\mathrm{Bu}$ etkilerin analizinde yapısal eşitlik modellemesi kullanılmıştır. Yapılan analizler sonucunda, reklamların bilgi vericiliğinin reklamlara yönelik tutumu olumlu yönde etkilediği bulunmuştur. Çalışmada reklamların olumsuz etkisine yönelik algıların ise, ebeveynlerin çocuklara yönelik televizyon reklamlarına ilişkin tutumları üzerinde de olumsuz etkisi olduğu tespit edilmiştir. Bu doğrultuda, pazarlama yöneticilerinin çocuklara yönelik reklam stratejilerini oluştururken reklamların bilgi verici olmasını ve çocuklar üzerinde ebeveynleri üzerinde olumsuz algılanacak etkiler bırakmamasını temel almaları önerilmektedir. Çocuk reklamlarının bilgi verici olmasının, çocuklarda olumlu etkiler bırakacak mesajlar vermesinin reklamların olumlu algılanmasına yardımcı olacağı değerlendirilmektedir. 
Çocuklara yönelik reklamların bilgi verici olarak algılanmasının ebeveynlerin çocuklarıyla reklam içeriği hakkında konuşmaları üzerinde de olumlu yönde etkisi olduğu görülmüştür. Başka bir deyişle, ebeveynler çocuklara yönelik reklamların bilgi verici olduğunu düşündüklerinde çocuklarına reklamları beğenip beğenmediğini soracaklar ve televizyon reklamlarını neden sevdiklerini öğrenmeye çalışacaklardır. Çocuklara yönelik reklamların bilgi verici olarak algılanmasının ebeveynlerin televizyon izleme kontrolü üzerinde etkisi incelendiğinde ise, bu yönde bir etki bulunamamıştır.

Reklamın olumsuz etkilerine yönelik algıların televizyon izleme kontrolünü olumlu yönde etkilediği bulunmuştur. Diğer bir ifadeyle, ebeveynler reklamın etkilerine yönelik olumsuz algılara sahipse, çocuklarının televizyonda hangi programları izleyeceği, ne zaman televizyon izleyebileceği ve günde kaç saat televizyon izleyebileceği konusunda kısıtlamalar getireceklerdir. Diğer yandan, çocuklara yönelik reklamların etkilerinin olumsuz algılanmasının ebeveynlerin çocuklarıyla reklam içeriği hakkında konuşmaları yönünde bir etkisi olmadığı bulunmuştur.

Ebeveynlerin çocuklara yönelik televizyon reklamlarına ilişkin tutumlarının çocuklarıyla reklam içeriği hakkında konuşmaları üzerinde olumsuz yönde etkisi olduğu bulunmuştur. Buna göre ebeveynler televizyon reklamlarına ilişkin olumlu tutumlara sahip olduğunda çocukların reklamları beğenip beğenmediğini sormaya ve televizyon reklamlarını neden sevdiklerini öğrenmeye çalışmaya gerek görmeyeceklerdir. Ayrıca televizyon reklamlarına ilişkin tutumların televizyon izleme kontrolü üzerindeki etkisi incelendiğinde ise, bu yönde bir etki bulunamamıştır. Bu bulgu, literatürde daha önce Chan ve McNeal (2002) ve Dens ve diğerleri (2007) tarafından yapılmış olan araștırmaları destekleyici niteliktedir.

İlgili literatür incelendiğinde araştırma konusu kapsamında sınırlı sayıda çalışmaya rastlanmıștır. Dolayısıyla bu değişkenler ile oluşturulan modelin gelecek araștırmalarda kullanılmak üzere literatüre katkı sağlayacağı düşünülmektedir. Bu modelin farklı araştırmalarda yeni değişkenler eklenerek kullanılması ve pazarlama yöneticilerinin çocuklara yönelik reklam stratejilerine ilişkin karar alırken bu modeldeki değişkenlerin etkilerini göz önünde bulundurmalarının faydalı olacağı düşünülmektedir.

Araştırmanın bazı kısıtları da söz konusudur. Öncelikle, araştırma tesadüfi olmayan örnekleme yöntemlerinden kolayda örnekleme yöntemi ile gerçekleştirilmiştir. Bu nedenle gelecekte yapılacak çalışmalarda tesadüfi yöntemlerin kullanılması elde edilecek bulguların geçerliliği ve güvenilirliği açısından faydalı olacaktır. Bunun yanında, çalışmanın Kocaeli dışındaki illeri ya da Kocaeli ilindeki farklı okullarda öğrencileri olan ebeveynleri kapsayacak şekilde tekrarlanması örneklemin genişleyerek araştırma bulgularının genellenebilirliğine katkı sağlayacaktır. Bununla birlikte farklı illerde çalışmanın tekrar edilerek bu çalışmada yer alan bulgularla karşılaştırılması da faydalı olacaktır. Ayrıca, bu çalışma araştırma modelindeki değişkenler üzerinde gerçekleştirilmiştir. Bu nedenle araştırma modelinin farklı değişkenlerle desteklenmesi, söz konusu araştırma bulgularının genişletilebilmesi bakımından faydalı olacaktır. Bunun yanında, farklı ölçeklerin kullanılarak araştırmanın tekrarlanması da önerilmektedir. 


\section{Kaynakça}

Asena, M. B. (2009). Gıda Reklamlarının Okul Öncesi Çocuklar Üzerindeki Etkilerinin Anneler Tarafından Değerlendirilmesi. Yayımlanmamış Yüksek Lisans Tezi, Bahçeşehir Üniversitesi, Sosyal Bilimler Enstitüsü.

Bal, D., \& Onay, A. (2020, Haziran). Televizyon Reklamları, Çocuk ve Tüketim: Tarz mısın, Değil misin? Galatasaray Üniversitesi İletişim Dergisi(32), 198-219.

Büyükbaykal, G. (2007). Televizyonun Çocuklar Üzerindeki Etkileri. İstanbul Üniversitesi İletişim Fakültesi Dergisi, 28, 31-44.

Chan, K., \& McNeal, J. U. (2002). Parental Concern About Television Viewing And Children's Advertising In China. International Journal for Public Opininon Research, 15(2), 151-166.

Çakır, H. (2019). Çocuğun Tüketim Davranışları Üzerindeki Reklam Etkisinin Ebeveyn Açısından Değerlendirilmesi. Kastamonu İletişim Araştırmaları Dergisi(2), 82-99.

Dağlı, Ö., \& Hacıbektaşoğlu, E. (2015). Televizyon Reklamlarının Çocuk-Aile İlişskisi ve Boş Zaman Kavramı Ekseninde Değerlendirilmesi. Üsküdar Üniversitesi Sosyal Bilimler Dergisi, 1(1), 183-212.

Dal, N. E., \& Dal, V. (2015). Çocukların Tüketici Olarak Sosyalleşme Sürecinde TV Reklamlarının ve Ailenin Rolü Hakkında Teorik Bir Çalışma. Mehmet Akif Ersoy Üniversitesi Sosyal Bilimler Dergisi, 7(13), 371-388.

Deloitte. (2019). Deloitte. Aralık 29, 2020 tarihinde Deloitte Web sitesi: https://www2. deloitte.com/tr/tr/pages/technology-media-and-telecommunications/articles/ turkiyede-tahmini-medya-ve-reklam-yatirimlari-2019-ilk-6-ay-raporu.html adresinden alındı

Dens, N., Pelsmacker, P. D., \& Eagle, L. (2007). Parental attitudes towards advertising to children and restrictive mediation of children's television viewing in Belgium. Young Consumers, 8(1), 7-18.

Doğan, M. (2003). Televizyon Reklamlarının Çocuklar Üzerindeki Etkisi. Yayımlanmamış Yüksek Lisans Tezi, Afyon Kocatepe Üniversitesi, Sosyal Bilişmler Enstitüsü.

Elden, M., \& Ulukök, Ö. (2006, Güz). Çocuklara Yönelik Reklamlarda Denetim ve Etik. Küresel İletişim Dergisi, 2, 1-22.

Engin, H. B. (2013). Çocuk Ve Reklam: Çocuklar Olması Gerekenden Erken Büyüyor. 1. Türkiye Çocuk ve Medya Kongresi, Bildiriler Kitabı (Cilt 1, s. 217-234). içinde İstanbul: Çocuk Vakfı Yayınları.

Ersoy, S., \& Özbaş, S. (2020). Çocukların Gıda Tüketimi Üzerine Televizyon Reklamlarının Etkisi. Akademik Gıda, 18(2), 172-179.

Fornell, C., \& Larcker, D. F. (1981). Evaluating Structural Equation Models with Unobservable Variables and Measurement Error. Journal of Marketing Research, 18(1), 39-50.

Gümüş, S. (2013). Ebeveynlerin ve Çocukların Televizyon Reklam İçeriklerine İlişkin Tutumlarının Organik ve Teknolojik Ürünlere Yönelik Karşılaştırmalı Analizi. Akademik Bakış Dergisi(37), 1-19.

Hair, J., Anderson, R. E., Babin, B. J., \& Black, B. (2010). Multivariate Data Analysis: A Global Perspective. Upper Saddle River: NJ: Pearson. 
Hair, J., Black, W. C., Babin, B. J., \& Anderson, R. E. (2014). Multivariate Data Analysis. Essex: Pearson Education Limited.

Hair, J., Wolfinbarger, M., Bush, R., \& Ortinau, D. (2009). Essentials of Marketing Research. New York: McGraw Hill.

İkinci, Ö. (2011). Reklamların Büyüyen Pazarı Çocuk Tüketiciler. TÜBİTAK Bilim ve Teknik Dergisi, 522, 66-69.

Karaboğa, T. (2020). Televizyon Reklamları Ve Çocuk. Akademik Sosyal Araştırmalar Dergisi, 8(101), 244-258.

Karaca, Y., Pekyaman, A., \& Güney, H. (2007). Ebeveynlerin Televizyon Reklam İçeriklerinin Çocuklar Üzerindeki Etkilerini Etik Açıdan Algılamalarına Yönelik Bir Araştırma. Sosyal Bilimler Dergisi, 9(2), 233-249.

Kline, R. B. (2016). Principles and Practice of Stuctural Equation Modeling (Fourth Edition b.). New York: The Guilford Press.

Loehlin, J. (2004). Latent Variable Models: An Introduction to Factor, Path, and Structural Equation Analysis (Fourth Edition b.). New Jersey: Lawrence Erlbaum Associates, Inc.

Morley, B., Chapman, K., Mehta, K., King, L., Swinburn, B., \& Wakefield, M. (2008). Parental awareness and attitudes about food advertising to children on Australian television. Australian and New Zealand Journal of Public Health, 32(4), 341-347.

Mukherji, J. (2005). Maternal Communication Patterns, Advertising Attitudes and Mediation Behaviours in Urban India. Journal of Marketing Communications, 11(4), 247-262. doi:10.1080/13527260500167223

Nefat, A., \& Dujmović, M. (2012). Children'S Advertising on Television and their Consumer Socialisation: Parents' Attitudes. Economic Research-Ekonomska Istraživanja, 25(1), 145-156. doi:10.1080/1331677X.2012.11517501

Pelenk, A. (2003). Televizyon Reklamlarının Çocuklar Üzerindeki Etkileri : Tüketicilerin Tutumlarının Değerlendirilmesi. Yayımlanmamış Yüksek Lisans Tezi, Eskişehir Anadolu Üniversitesi, Sosyal Bilimler Enstitüsü.

Quadır, S. E., \& Akaroğlu, G. (2009). Televizyon Reklâmlarının Çocuk Tüketiciler Üzerine Görsel Etkilerinin Bir İncelemesi. Selçuk İletişim Fakültesi Akademik Dergisi, 6(1), 78-98.

Rose, G. M., Bush, V. D., \& Kahle, L. (1998). The Influence of Family Communication Patterns on Parental Reactions toward Advertising: A Cross-National Examination. Journal of Advertising, 27(4), 71-85.

RTÜK. (2018). RTÜK. Ocak 5, 2021 tarihinde RTÜK Web sitesi: https://www.rtuk. gov.tr/assets/Icerik/AltSiteler/\%C3\%A7ocuklar\%C4\%B1n\%20yeni\%20 medya\%20al\%C4\%B1\%C5\%9Fkanl\%C4\%B1klar\%C4\%B1\%20ve\%20siber\%20 zorbal\%C4\%B1k\%20ara\%C5\%9Ft\%C4\%B1rmas\%C4\%B1/cocuklarin-yenimedya-kullanimlari-ve-siber-zorbalik.pdf adresinden alındı

Schermelleh-Engel, K., Moosbrugger, H., \& Müller, H. (2003). Evaluating the Fit of Structural Equation Models: Tests of Significance and Descriptive Goodness-of-Fit Measures. Methods of Psychological Research Online, 8(2), 23-74. 
TÜİK. (2020). Türkiye İstatistik Kurumu. Ocak 2, 2021 tarihinde Türkiye İstatistik Kurumu Web sitesi: https://data.tuik.gov.tr/Bulten/Index?p=IstatistiklerleCocuk-2019-33733 adresinden alındı

Vodinalı, S. (2016). Tüketim kültürü bağlamında reklam ve çocuklar üzerindeki etkileri: "Maret yoook mu? Reklamı üzerine bir çözümleme". International Journal of Social Sciences and Education Research, 2(1), 162-182.

Wolin, L. D., Korgaonkar, P., \& Lund, D. (2002). Beliefs, attitudes and behaviour towards Web Advertising. International Journal of Advertising, 21(1), 87-113.

Young, B. M., Bruin, A. d., \& Eagle, L. (2003). Attitudes of Parents Toward Advertising to Children in the UK, Sweden and New Zealand. Journal of Marketing Management, 19(3-4), 475-490. 


\title{
The Effect of Parents' Perceptions on Their Attitude and Mediation in Television Advertising Toward Children
}

\author{
Duygu Talih Akkaya (Asst. Prof. Dr.) \\ Şeniz Özhan (Asst. Prof. Dr.)
}

\section{Extended Abstract}

In the study, it was aimed to investigate the effects of parents' perception of television commercials towards children on their attitudes and mediation. Considering the literature review conducted for this purpose, it is predicted that parents' perceptions of television advertisements for children will affect their attitudes and mediation.

In the research, an answer is sought for the question of to what extent television advertisements for children affect parents' perceptions and attitudes.In addition, whether the perceptions and attitudes of the parents have an effect on the television watching control they apply to their children when they talk with their children about advertising content is also included in the research questions.

Despite the fact that the Internet and social media are rapidly rivaling television, television still maintains its place as one of the important means of socializing and getting news for many families.This situation causes families to see television as a means of leisure time and thus children to meet with television at an early age. Television, which is at the center of critical studies today, continues to exist as an indispensable communication tool by millions of people despite all the criticisms (Dağlı \& Hacıbektaşoğlu, 2015). Children, the smallest individuals of the society, are still affected by television, which is still the most common and effective mass communication tool (Büyükbaykal, 2007). Although television ads target individuals of different age groups, children are among their most important audiences and consumers. Television advertisements for children, besides attracting the attention of children and transforming this interest into purchasing behavior, can also be effective on their socialization with the consumer lifestyle they offer (Karaboğa, 2020). In general, parents have negative attitudes towards television advertising towards children and feel the pressure of their children to buy products that they do not really need (Nefat \& Dujmović, 2012). There are studies in the literature that dealt with the attitudes of parents towards television advertisements towards children with different methods. In most of these studies, it was concluded that parents displayed a negative attitude towards television advertisements for children. However, a limited number of studies have been found on the effect of parents' perceptions towards these advertisements on their attitudes and mediation. Therefore, it is thought that the study will contribute significantly to the literature on the subject.

The survey study was conducted with the parents of two primary schools in Kocaeli province Gölcük district in the 2019-2020 academic year. Due to time and cost constraints, the convenience sampling method, one of the non-random sampling methods, was used to determine the participants of the study, and the research data were collected by face-to-face survey method.. The valid number of data collected from parents is 247. To measure parental perceptions, Young et al. (2003) for Wolin et al. (2002), and for parental mediation, the scales in the studies of Mukherji (2005) were used. The hypotheses 
developed according to the research aim and model were tested with SPSS Sciences) and AMOS 24 statistical package programs.

As a result of the analysis, it was found that the informative nature of the ads positively affected the attitude towards the advertisements. In the study, it was found that perceptions about the negative effect of advertisements also had a negative effect on parents' attitudes towards television commercials towards children. It has been observed that the perception of advertisements for children as informative also has a positive effect on parents' conversations with their children about ad content. When the effect of the perception of advertisements aimed at children as informative on the television viewing control of parents was examined, no such effect was found. It was found that perceptions about the negative effects of advertising positively affect the control of television watching. On the other hand, it was found that the negative perception of the effects of advertisements for children does not have an effect on parents' talking with their children about the ad content. It was found that the attitudes of the parents towards the television commercials towards children had a negative effect on their conversations with their children about the advertisement content. Accordingly, when parents have positive attitudes towards television commercials, they will not find it necessary to ask whether the children like the commercials and try to find out why they like the television commercials. In addition, when the effect of attitudes towards television advertisements on television viewing control is analyzed, no such effect was found.

Keywords: Advertising, Television Advertising Toward Children, Parental Perceptions, Parental Attitude, Parental Mediation.

Bu makale intihal tespit yazılımlarıyla taranmıştır. Intihal tespit edilmemiştir.

This article has been scanned by plagiarism detection softwares. No plagiarism detected.

Bu çalışmada "Yükseköğretim Kurumları Bilimsel Araştırma ve Yayın Etiği Yönergesi” kapsamında uyulması belirtilen kurallara uyulmuştur.

In this study, the rules stated in the "Higher Education Institutions Scientific Research and Publication Ethics Directive" were followed.

Yazarların çalışmadaki katkı oranları eşittir.

The authors' contribution rates in the study are equal.

Çalışma kapsamında herhangi bir kurum veya kişi ile çıkar çatışması bulunmamaktadır.

There is no conflict of interest with any institution or person within the scope of the study.

Etik Kurul İzni I Ethics Committee Permission

Yalova Üniversitesi Sosyal Bilimler Etik Kurulu 16/05/2019 tarih ve 93772138 numaralı toplantısında alınan karar çerçevesinde çalışma etik açıdan bir sakınca içermemektedir.

Within the framework of the decision taken during the meeting by Yalova University Social Sciences Ethics Committee dated 16/05/2019 and numbered 93772138; the study does not contain any ethical issues. 